\title{
Kriteria Poligami serta Dampaknya melalui Pendekatan Alla Tuqsitu Fi al- Yatama dalam Kitab Fikih Islam Wa Adillatuhu
}

\author{
Oleh \\ Eka Hayatunnisa dan Anwar Hafidzi \\ Fakulstas Syariah dan Ekono \\ mi Islam \\ Universitas Islam Negeri Antasari Banjarmasin \\ Email: ekahayatunnisa@gmail.com ; anwar.hafidzi@gmail.com
}

\begin{abstract}
Polygamy is a provision of Islamic law that allows more than one wife. This issue is alluded to in the Qur'an and there are verses that provide the legal basis for polygamy. Basically Islam allows polygamy which in Al Quran mentioned that maximum polygamy is given limit to 4 wives. In this regard, there are various problems that are understood diverse by some scholars, especially regarding the impact of polygamy in today's modern era. Therefore this study will focus on the study of the 2 books of fiqh namely Fikih Islaam wa Adillatuhu and Fikiih Sunnah, both of which discuss the impact of polygamy. The author tries to contextualized the worldview of both books in understanding the polygamy that occurs in the present. This research uses descriptive analytic method of the two books mentioned above. Through this paper, it appears that the impact of polygamy is very detrimental to the women, more than that it also raises new problems in the community.
\end{abstract}

Keywords: Polygamy, Wabbah az Zuhaili, negative impact.

Abstrak: Poligami merupakan ketentuan hukum Islam yang membolehkan beristeri lebih dari satu. Permasalahan ini disinggung dalam al quran dan ada ayatayat yang memberikan dasar hukum pada poligami. Pada dasarnya Islam membolehkan poligami yang dalam al quran disebutkan bahwa poligami maksimal di berikan batasan sampai 4 org isteri. Mengenai hal ini terdapat berbagai persoalan dan problematika yang dipahami secara beragam oleh beberapa ulama, terutama mengenai dampak poligami di era modern sekarang ini. Oleh karena itu penelitian ini akan berfokus pada kajian terhadap 2 kitab fikih yakni Fikih Islaam wa Adillatuhu dan Fikiih Sunnah, yang keduanya membahas tentang dampak poligami. Penulis mencoba mengkontestualisasikan cara pandang kedua kitab ini dalam memahami poligami yang terjadi di masa kini. Penelitian ini menggunakan metode desktiptif analitik terhadap dua kitab yang telah disebutkan di atas. Melalui tulisan ini, tampak bahwa dampak poligami sangat merugikan pihak perempuan, lebih dari itu ia juga justru menimbulkan masalah baru di lingkungan masyarakat.

Kata kunci : Poligami, Wabbah az Zuhaili, dampak negatif. 


\section{Latar Belakang}

$$
\text { Poligami }{ }^{1} \text { dapat diartikan }
$$
sebagai suatu ikatan perkawinan dimana salah satu pihak yakni suami dalam satu waktu bersamaan mengawini lebih dari satu orang isteri. Meski dalam ajarannya, Islam melegalkan poligami tetapi pandangan kaum wanita terhadap poligami tetap mengangap sebagai suatu upaya eksploitasi wanita ${ }^{3}$ demi kebutuhan biologis kaum Adam ${ }^{4}$, sementara dari kaum Adam sendiri ini dianggap sebagai sesuatu yang lumrah. $\mathrm{Hal}$ seperti inilah nampaknya dipahami oleh umat Islam tentang poligami dan kebolehannya ${ }^{5}$. Seolah-olah hukum Islam memberikan hak untuk berpoligami tanpa mengenal batasan. Kemudian hak dan kebolehanny berpoligami ini digunakan tanpa arif dan bijaksana. Walupun disisi lain memang sudah menjadi ketentuan dalam hukum Islam bahwa laki-laki boleh beristeri lebih dari satu.

\footnotetext{
1 Lihat ISLAM, "A. Pengertian Poligami," Hal. 16.

2 Lihat Andaryuni, "POLIGAMI DALAM HUKUM KELUARGA DI DUNIA ISLAM," Hal. 99.

3 Lihat NABIL dan others, "TINJAUAN MAQÂȘID ASY-SYARÎ'AH TERHADAP THE CODE OF PERSONAL STATUS TAHUN 1958 PASAL 18 TENTANG POLIGAMI DI TUNISIA," Hal. ii.

4 Lihat HANAFI-NIM dan others, "HYPERSEKS DAN AKIBATNYA DALAM KEHIDUPAN RUMAH TANGGA (STUDI PUTUSAN PENGADILAN AGAMA SLEMAN NO. 532/Pdt-G/2000/Sm)," Hal. 9.

${ }^{5}$ Lihat Andaryuni, "POLIGAMI DALAM HUKUM KELUARGA DI DUNIA ISLAM," Hal. 101.
}

Banyak kaum wanita yang memandang poligami sebagai sesuatu yang menakutkan bahkan sama menakutkannya dengan sebuah perceraian. Banyak kalangan wanita juga yang beranggapan jika suami mereka berkeinginan untuk melakukan poligami ini justru menandakan bahwa rumah tangganya berantakan gara-gara poligami. Dan memang poligami itu sendiri sudah menjadi suatu hal yang tidak asing lagi untuk diperdengarkan, isu-isu mengenai pologami merebak di mana-mana, banyak kalangan masyarakat dan para tokoh terkenal di Indonesia yang juga melakukan poligami.

Dalam hukum Islam itu sendiri mengenai poligami ini disamping Allah menunjukkan adanya hak untuk beristeri lebih dari satu, Allah juga memberi suatu aturan pembatasan poligami dan syarat-syaratnya yang gunanya itu adalah untuk kemaslahatan diantara keduanya. Mayoritas ilmuan klasik dan pertengahan berpendapat bahwa poligami adalah boleh secara mutlak. Sementara mayoritas pemikir kontemporer dan perundangundangan muslim modern membolehkan poligami dengan syaratsyarat dan dalam kondisi tertentu yang sangat terbatas. Dari firman Allah Swt dalam surat An- Nisa' ayat 3 lah sebenarnya pangkal atau permasalahan mengenai pembatasan poligami itu sendiri apakah di artikan dengan hanya 
boleh beristeri sampai dengan 4 saja, atau 9, atau bahkan tanpa batas ${ }^{6}$.

Sebagian dari masyarakat kita kurang atau tidak sepakat dengan poligami ${ }^{\top}$ dan mereka menentang praktik poligami yang ada sekarang ini, karena efek negatifnya sangat besar bagi keluarga dan banyak menyakiti kaum perempuan. Namun, sebagian yang lain menyetujui poligami dengan alasan beragam. Kelompok ini beralasan bahwa meskipun poligami memiliki banyak resiko, tetapi bukanlah sesuatu yang dilarang oleh agama, khususnya Islam.

\section{Banyaknya} masayarakat mengenai poligami. Dan pada dasarnya fenomena poligami ini sudah dianggap lumrah terjadi bahkan tidak hanya terjadi pada masa Rasulullah SAW, tetapi poligami sudah mendunia hingga ke polosok

6 Praktik poligami sebelum datangnya Islam dilakukan tanpa adanya batas jumlah isteri, tetapi setelah Islam d Dengan adanya Q.S Annisa: 3 yang memberikan aturan batasan sampai empat orang isteri akan tetapi ada pandangan dari sebagian mazhab Dzahiriah yang meberikan tafsiran bahwa mastna wa sulasa wa ruba' ditafsirkan dengan menjumlah sehingga diartikan boleh berpoligami sampai 9 isteri, bahkan pandangan lain juga muncul dari sebagian ulama mazhab ini dengan menafsirkan lafal mastna $=$ dua-dua, lafal sulasa $=$ tiga-tiga, lafal ruba' = empat-empat. Oleh karena itu menurut pandangan ini laki-laki boleh berpoligami sampai 18 orang. Lihat Abi' Abdillah Muhammad bin Ahmad ibn Anshari Al-Qurthubi, Al jami' li ahkam Al Qur'an (Bairut: Dar Al-Fikr, 1999) III : 13-14 (13251326). Bandingkan juga dengan Ulfah, "Poligami menurut Muhammad Syahrur dalam pandangan hukum Islam," Hal. 6.

${ }^{7}$ Lihat Hidayat, "Pemikiran Muhammad Quraish Shihab Tentang Poligami,” Hal. 16. manapun, untuk itulah maka penulis akan menguraikan bagaimana pandangan dari Wahbah az-Zuhaili dalam karyanya Fikib Islam wa Adillatubu dan Sayyid Sabiq dalam karyanya Fikih Sunnah mengenai dampak negatif dari poligami.

\section{Kajian Naskah Sebab Pembatasan Empat Orang Isteri dalam Al Fiqh Al Islami Wa Adillatuh Dan Fikih Sunnah}

1. Al Fiqh Al Islami Wa Adillatuh

ففي المشروع غنى وكفاية، وسد للباب أمام الانخرافات،

أوما قد يتخذه بعض الرجال من عشيقات أو خدينات

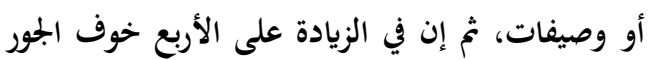

عليهن بالعجز عن القيام بحقوقهن؛ لأن الظاهر أن

الرجل لايقدر على الوفاء بحقوقهن، وإلى هذا أشار

القرآن الكريم بقوله عز وجل: \} فإن خفتم ألا تعدلوا

فواحدة] [النساء:4/3] أي لا تعدلوا في القَسْم

والجماع والنفقة في زواج المثنى، والثلاث، والرباع، فواحدة، فهوأقرب إلى عدم الوقوع في الظلمه

Alasan pembatasan 4 orang isteri menurut Wahbah az Zuhaili dalam kitab beliu yaitu Fikih Islam wa Adillatuhu bahwa poligami dibatasi agar semua celah yang dapat menimbulkan kepada berbagai penyimpangan dapat ditutup. Serta perilaku yang mungkin saja dilakukan oleh beberapa orang laki-laki dengan memiliki kepemilikan wanita idaman lain tanpa sepengetahuan isterinya,

8 Wahbah Az-Zuhaili, Fikih Islam Wa Adillatubu, (Damaskus: Dar Al-Fikr,1985), Hal. 167 
dan juga kepemilikan wanita penghibur.

\section{Selanjutnya menurut} pandangan Wahbah az Zuhaili dalam bertambahnya jumlah isteri dari satu orang menjadi empat, dikhawatirkan memicu perbuatan maksiat dari para isteri akibat suaminya tidak mampu dalam memenuhi hak-hak para isteri. Karena secara zahir, seorang laki-laki tidak mampu memenuhi hak-hak mereka.

2. Fikih Sunnah

ذلك أن الحياة المنزلية تتطلب نفقات باهظة،

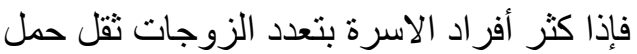

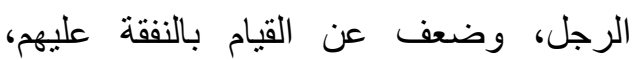

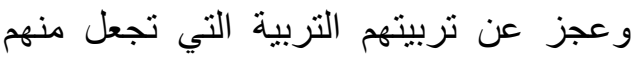

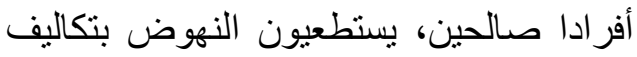

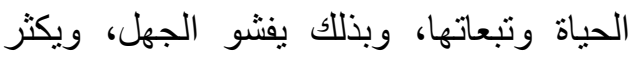
المتعطلون، ويتشرد عدد كبير من أفراد الأمة، فيثبون و هم يحملون جر اثيم الفسادو

Sayyid Sabiq memberikan pandangan bahwa ketika seorang lakilaki ingin berpoligami maka langkah itu harus melewati tes uji penelitian yang dilakukan oleh kehakiman dan instansi terkait yang memiliki wewenang, hal ini berkaitan dengan kemampuannya secara materi untuk menafkahi para isteri dan anak. Instansi inilah yang selanjutnya berhak memberikan izin kepadanya untuk menikah lagi. Menurut Sayyid Sabiq hal ini penting dilakukan karena kehidupan berumah tangga memerlukan biaya yang cukup tinggi. Apabila jumlah anggota keluarga

9 Sayiid Sabiq, Al Fiqh Al Sunnah, (Bairut: Darul Fikri, 1983), hal. 108 bertambah dengan berpoligami, secara otomatis beban yang harus ditanggung pihak laki-laki (suami) sebagai kepala runmah tangga akan semakin berat. Suami bisa jadi tidak akan mampu melaksanakan kewajibannya dalam memberikan nafkah, mengasuh, dan mendidik keluarganya agar menjadi anggota masyarakat yang baik, yang mampu bangkit dan memikul beban tanggung jawab dan keperluan hidup sehari-hari. Ketidakmampuan ini akan melahirkan kebodohan, semakin bertambahnya angka pengangguran, juga terlantarnya sebagian besar masyarakat, sehingga para pemuda yang ada hanya menjadi penyakit sosial yang merusak tatanan masyarakat.

Menuru Sayyid Sabiq diantara laki-laki apabila memiliki isteri lebih dari satu banyak dari laki-laki itu yang menelantarkan anak-anak dan isterinya, bahkan juga menutupi hak mereka sebagai ahli warisnya, sehingga menurut beliau permasalahn seperti ini dapat menumbuhkan benih permusuhan dan dengki di antara saudara tiri. Permusuhan ini akan terus berkelanjutan dan semakin meluas hingga di kalangan keluarga dan semakin merajalela, bahkan tak jarang diantara isteri terjadi kasus pembunuhan agar dapat menjatuhkan satu sama lain.

\section{Biografi Tokoh}

1. Wahbah Az-Zuhaili

a. Sejarah Singkat Wahbah AzZuhaili 
Tokoh yang bernama Syaikh Prof Dr. Wahbah Az-Zuhaili merupakan seorang ulama fikih kontemporer yang menduduki peringkat dunia. Bagaimana tidak, peringkat itu dibuktikan dengan banyaknya karya beliau yang mendunia. Pemikiran beliau yang beliau tuangkan dalam salah satu kitab fikihnya yang berjudul Al Fiqh Al Islami Wa Adillatuh menyebar ke seluruh dunia. Beliau lahir di desa Dir'Athiah, Siria pada tahun 1932 M. Beliau memulai pelajaran dasar di desanya. Kemudian melanjutkan pendidikannya di Kuliah Syar'iyah dan tamat pada 1952 M. Dalam perjalanan hidupnya menuntut ilmu beliau banyak memperoleh beberapa gelar. Ia memperoleh ijazah sarjana di Al-Azhar dan juga memperoleh ijazah takhassus pengajaran bahasa Arab di Al Azhar ${ }^{10}$. Kemudian memperoleh ijazah Licence (Lc) bidang hukum di Universitas 'Ain Syams, Magister Syariah dari Fakultas Hukum Universitas Kairo pada tahun 1959 dan Doktor pada tahun $1963 \mathrm{M}$

Motto hidup beliau adalah, "Inna sirra an-najah fi al-hayah ibsan ashshilah billah 'azza wa jalla", yang artinya (Sesungguhnya, rahasia kesuksesan dalam hidup adalah membaikkan hubungan denganAllah 'Azza wa jalla). Syaikh Wahbah Az Zuhaili sangat produktif menulis,

10 Fatimah, "Waris kalalah dalam pandangan wahbah az-zuhaily (tafsir Qs. alnisa'(4) ayat 12 dan ayat 176)," Hal. 16. mulai dari artikel dan makalah sampai kepada kitab besar yang terdiri atas enam belas jilid. ${ }^{11}$ Keilmuan beliau di spesifikasin pada bidang Fiqh dan Ushul Fikih alIslami. ${ }^{12}$ Dr. Badi As Sayyid Al Lahham dalam biografi Syaikh Wahbah yang ditulisnya dalam buku yang berjudul, Wahbah Az Zuhaili al-`Alim, Al Faqih, Al Mufassir menyebutkan 199 karya tulis Syaikh Wahbah selain jurnal.

Diantara guru-guru beliau yakni : M. Hashim al-Khatib asy Safie dengan mempelajari fikih asySyafie; dari Abdul Razaq al-Hamasi mempelajari ilmu fikih, dari Muhammda Yassin dipelajari ilmu hadis, dari Judat al-Mardini dengan mempelajari ilmu faraid dan wakaf, mempelajari ilmu tafsir dari Hassan Habnakah al-Midani, mempelajari ilmu bahasa arab dari Muhammad Shaleh Farhur, mempelajari ilmu ushul fikih dan mustalah hadis dari Muhammad Lutfi al-Fayumi, mempelajari ilmu akidah dan kalam dari Mahmud al-Rankusi. Dan selama di mesir beliau juga berguru dengan Muhammad Abu Zuhrah, Mahmud Shaltut, Abdul Rahman Taj, Isa Manun, Ali Muhammad

\footnotetext{
11 NIKMAH-NIM dan others, "WAHBAH AZ-ZUHAILI DAN ISTIDLALNYA TENTANG ZAKAT PROPERTI."

12 MUHAFID dan others, "STUDI KRITIS TERHADAP PEMIKIRAN ASSAYYID SABIQ TENTANG WAKAF UANG DAN RELEVANSINYA DI INDONESIA PROPOSAL SKRIPSI," Hal. VII.
} 
Khafif , Jad al-Rabb Ramadhan, Abdul Ghani, Abdul Khaliq, dan Muhammad Hafiz Ghanim. ${ }^{13}$

\section{b. Karya-Karya Wahbah Az- Zuhaili}

Di antara karyanya terpenting adalah: $A$ l Figh Al Islami wa Adillatuh, At Tafsir Al Munir, Al Figh Al Islami fi uslubih Al Jadid, Nazariyat Adh Dharurah Asy Syari ah, Usbul Al Fiqh Al Islami, Az Zharai ah fi As Siyasah Asy Syari ah, Al 'Alaqat ad-Dualiyah fi Al Islam, Jubud Taqnin Al Fiqh Al Islami, Al Fiqh Al Hanbali Al Muyassar. Beliau juga menulis kitab tafsir sampai enam belas jilid diantaranya : At Tafsir Al Wasith tiga jili, Al Ijaz fi Al Qur"an, Al Qishshah AlQur"aniyah, Tafsir Al Munir ${ }^{14}$

Hal ini pula menyebabkan beliau layak untuk disebut sebagai ahli tafsir. Bahkan, ia juga menulis tentang akidah, sejarah, pembaharuan pemikiran Islam, ekonomi, lingkungan hidup, dan bidang lainnya. Jadi, Syaikh Wahbah bukan hanya seorang ulama fikih, tetapi juga beliau adalah seorang

13 FAUZI dan others, "BISNIS ONLINE PTC (PAID TO CLICK) STUDI PERBANDINGAN ANTARA HUKUM ISLAM DAN HUKUM POSITIF (KUHPERDATA)," Hal.V.

14 Fatimah, "Waris kalalah dalam pandangan wahbah az-zuhaily (tafsir Qs. alnisa'(4) ayat 12 dan ayat 176)," Hal. 18. ulama dan pemikir Islam peringkat dunia. ${ }^{15}$

\section{Biografi, Karya dan Pemikiran Hukum Sayyid Sabiq}

\section{a. Biografi Sayyid Sabiq}

Sayyid Sabiq lahir di di Istanha, Mesir, tahun 1915. Nama lengkap beliau adalah Sayyid Sabiq Muhammad at-Tihamiy. Silsilahnya berhubungan dengan khalifah ketiga, Utsman bin Affan (576-656) ${ }^{16}$. Pada usia antara 10 dan 11 tahun, ia telah menghafal Al-Qur'an dengan baik. Setelah itu, ia langsung memasuki perguruan al-Azhar di Cairo dan di sinilah ia menyelesaikan seluruh pendidikan formalnya mulai dari tingkat dasar sampai tingkat takhassus (kejuruan). Pada tingkat akhir ini ia memperoleh asy-Syahadah al-'Alimyyah (1947), ijazah tertinggi di Universitas al-Azhar ketika itu, kurang lebih sama dengan ijazah doktor. Meskipun beliau dari keluarga penganut Mazhab Syafi'i'17, namun pada saat menempuh studinya di Universitas al-Azhar beliau mengambil Mazhab Hanafi. Namun demikian, Sayyid Sabiq mempunyai kecenderungan suka membaca dan menelaah mazhab-mazhab lain. Di

\footnotetext{
15 NIKMAH-NIM dan others, "WAHBAH AZ-ZUHAILI DAN ISTIDLALNYA TENTANG ZAKAT PROPERTI."

16 Abdul Aziz Dahlan, Ensiklopedi Hukum Islam, (Jakarta: PT Ichtiar Baru Van Hoeve, 1997, Jilid 5), hlm. 1614.

17 PEMBERIAN dan ANAK-ANAK, “PERSETUJUAN PEMBIMBING," Hal. 30.
} 
antara guru-gurunya adalah Syekh Mahmud Syaltut dan Syekh Tahir adDinari, keduanya dikenal sebagai ulama besar di al-Azhar ketika itu. Ia juga belajar kepada Syekh Mahmud Khattab, pendiri al-Jam'iyyah asySyar'iyyah li al-'Amilin fi al-Kitab wa asSunnah (Perhimpunan Syariat bagi Pengamal Al-Qur'an dan Sunah Nabi). Al-Jam'iyyah ini bertujuan mengajak umat kembali mengamalkan Al-Qur'an dan sunah Nabi SAW tanpa terikat pada mazhab tertentu. ${ }^{18}$

\section{b. Karya-karyanya}

Sayyid Sabiq menulis sejumlah buku yang sebagiannya beredar di dunia Islam, termasuk di Indonesia, antara lain:Yahudi dalam Al-Qur'an, Unsur-Unsur Dinamika dalam Islam, Akidah Islam, Kemurtadan, Salat, Bersuci, dan Berwudu, Puasa, Karangan Bunga, Dakwah Islam, Fikih Berdasarkan Sunah Nabi, Keislaman Kita, Keistimewaan dan Ciri Syariat Islam, Manasik Haji dan Umrah. Artikel-Artikel Islam, Sumber-Sumber Syariat Islam, Adat Kebiasaan: Wajib Menghilangkan Berbagai Kemungkaran Sukaria. ${ }^{19}$ Sayyid Sabiq seorang ulama yang bersikap moderat, menolak paham yang menyatakan tertutupnya pintu ijtihad. Dalam menetapkan hukum, ia senantiasa merujuk langsung pada al-Qur'an dan sunnah Nabi Saw, tanpa terikat pada mazhab tertentu,

\footnotetext{
18 Ibid., Hal. 31-32.

19 Ibid., Hal. 34.
}

sehingga tidak jarang ia mengemukakan pendapat para ulama yang disertakan dengan dalilnya tanpa melakukan tarjib (menguatkan salah satu dan dua dalil). Lebih dari itu, menurutnya setiap orang boleh memilih pendapat dan pemahaman yang lebih mudah dan ringan bagi dirinya. ${ }^{20}$

\section{Konsep Poligami dalam Islam}

Islam melegalkan poligami dengan batasan sampai empat orang dan mewajibkan berlaku adil kepada mereka, baik dalam urusan pangan, pakaian, tempat tinggal, serta lainnya yang bersifat kebendaan tanpa membedakan antara istri yang kaya dan istri yang miskin, yang berasal dari keturunan tinggi dengan yang rendah dari golongan atas dengan golongan bawah ${ }^{21}$.

Bila suami khawatir berbuat zalim ${ }^{22}$ dan tidak mampu memenuhi semua hak-hak mereka, maka hendaknya tidak berpoligami. Bila yang sanggup dipenuhinya hanya tiga, maka tidak dianjurkan baginya menikah dengan empat orang. Jika dia hanya mampu memenuhi hak dua orang istri maka tidak dianjurkan baginya untuk menikah sampai tiga kali. Begitu juga kalau ia khawatir berbuat zalim dengan mengawini dua orang perempuan maka baginya tidak

\footnotetext{
20 Ibid., Hal. 35.

21 Sohari Sahrani. Fikih Munakahat. Jakarta: Raja Grafindo Persada, 2010. Cetakan ke II, hal 172.

22 Lihat, Kamus KBBI (Kamus Besar Bahasa Indonesia)
} 
dianjurkan untuk melakukan poligami.

Sebagaimana dalam firman Allah SWT dalam surat An- Nisa' ayat 3: Dan jika kamu takut tidak akan dapat berlaku adil terhadap (hak-bake) perempuan yang yatim (bilamana kamu mengawininya), maka kawinilah wanitawanita (lain) yang kamu senangi : dua, tiga atau empat. Kemudian jikea kamu takut tidak akan dapat Berlaku adil, maka (kawinilah) seorang saja, atau budak-budak yang kamu miliki. Yang demikian itu adalah lebih dekat kepada tidak berbuat aniaya.

Dalam sebuah hadits Nabi SAW juga disebutkan: Dari Abi Hurairah R.a sesunggubnya Nabi Saw. bersabda," Barang siapa yang mempunyai dua orang istri lalu memberatkan pada salah satunya, maka ia akan datang di hari kiamat nanti dengan punggung miring”. (HR. Abu Daud, Tirmidzi, Nasa'i, dan Ibnu Hibban). ${ }^{23}$

Keadilan yang diwajibkan oleh Allah dalam ayat diatas, tidaklah bertentangan dengan firman Allah Swt. Dalam Surat An-Nisa ayat 129: Dan kamu sekali-kali tidak akan dapat berlaku adil di antara isteri-isteri(mu), walaupun kamu sangat ingin berbuat demikian, karena itu janganlab kamu terlalu cenderung (kepada yang kamu cintai), sebingga kamu biarkan yang lain terkatung-katung. dan jika kamu mengadakan perbaikan dan memelibara diri (dari kecurangan), maka sesunggubnya

23 Sayyid Sabiq, Fiqih Sunnah. Bandung: Alma'arif, 2008. Cetakan XX, hal 381
Allab Maha Pengampun lagi Maha Penyayang.

Kalau ayat tersebut seolah-olah bertentangan dengan masalah berlaku adil, pada ayat 3 surat AnNisa, diwajibkan berlaku adil, sedangkan ayat 129 meniadakan berlaku adil. Pada hakikatnya, kedua ayat tersebut tidaklah bertentangan karena yang dituntut disini adalah adil dalam masalah lahiriyah bukan kemampuan manusia. Dan berlaku adil yang ditiadakan dalam ayat diatas adalah adil dalam masalah cinta dan kasih sayang. ${ }^{24}$ Abi bakar bin Arabi mengatakan bahwa memang benar apabila keadilan dalam cinta itu berada di luar kesanggupan manusia. Sebab, cinta itu adanya dalam genggaman Allah SW'T yang mampu membolak-balikannya menurut kehendak-Nya. Begitu juga dengan bersetubuh, terkadang ia bergairah dengan istri yang satu tapi tidak begitu bergairah dengan istrinya yang lain. Dalam hal ini, apabila tidak sengaja, ia tidak terkena hukuman dosa karena berada diluar kemampuannya. Oleh karen itu, ia tidaklah dipaksa untuk melakukannya.

Aisyah R.a. berkata: Rasullullab Saw. selalu membagi giliran sesama istrinya dengan adil dan beliau pernah berdo'a: Ya Allab! Ini bagianku yang dapat aku kerjakan. Karena itu janganlah engkau mencelakakanku tentang apa yang Engkau Kuasai, sedang aku tidak menguasainya. "Abu Dawnd berkata

\footnotetext{
${ }^{24}$ Sohari Sahrani, Op-cit., hal 175
} 
bahwa yang dimaksud dengan "Engkau tetapi aku tidak menguasai", yaitu bati. (HR.Abu

Dawud, Tirmidzi,Nasa'i dan Ibnu Majah). ${ }^{25}$

1. Dasar Hukum Poligami

Dasar hukum mengenai poligami dalam pernikahan disebutkan secara jelas dan tegas dalam al-Qurean. Ayat yang sering menjadi rujukan para ulama dalam hal poligami adalah QS. an-Nisa ayat 3 yaitu:

وَإِنْ خِفْتُمْ أَلَّا تُقْسِطُوا فِي الْيَتَامَى فَانْكِحُوا مَا

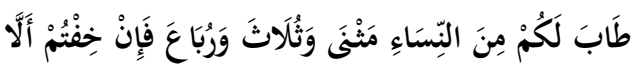

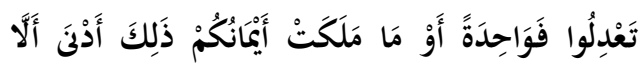

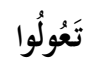

"Iika kamu khawatir tidak akan dapat berlaku adil terbadap perempuan perempuan yatim bila kamu mengawininnya) maka kawinilah perempuan-perempuan lain yang kamu senangi: dua, tiga atau empat. Kemudian jika kamu khawatir tidak dapat berlaku adil (dalam hal-hal yang bersifat labiriyyah jika mengawini lebih dari satu), maka kawinilah seorang saja atau budak-budak yang kamu miliki. Yang demikian itu lebih dekat kepada tidak berbuat aniaya."

2. Syarat Poligami

a. Membatasi jumlah isteri yang akan dikahwininya .Syarat ini telah disebutkan oleh Allah SWT dengan firman-Nya: "Maka berkawinlah dengan sesiapa yang kamu berkenan dari perempuanperempuan (lain): dua,

25 Sayyid Sabiq, Op-cit hal 383. tiga atau empat." (Al-Qur'an, Surah Al-Nisa' ayat 3). ${ }^{26}$

b. Mampu Berlaku adil sudah dengan tegas diterangkan serta dituntut agar para suami bersikap adil jika akan berpoligami. Jika ia takut tidak dapat berbuat adil bilan sampai empat orang isteri, maka cukuplah bagi laki-laki itu untuk tiga orang isteri saja. Tetapi kalau itupun dirasa masih juga ia tidak dapat berbuat adil, maka cukuplah baginya untuk dua orang isteri saja. Dan selanjutnya kalau dua itu pun masih khawatir nantinya tidak akan berbuat adil, maka hendaklah baginya untuk menahan dan menikah dengan seorang isteri saja karena berlaku adil itu merupakan sesuatu yang wajib. ${ }^{27}$

c. Mampu Memberikan Nafkah Lahir dan juga Batin. Dalam soal keadilan memberikan nafkah lahir dan batin untuk isterinya hendaklah seorang suami tidak mengurangi nafkah lahir dan batin dari salah seorang isterinya dengan alasan bahawa isterinya itu lebih kaya darinya atau sumberkeuangannya lebih banyak, sehingga seorang suami dengan alasan itu dia dapat menghilangkan kewajibannya untuk memberi nafkah, kecuali jika si isteri tersebut rela. Karena seorang suami yang berpoligami mempunyai

26 Ahmad, "ANALISIS MASLAHAH MURSALAH TERHADAP PERJANJIAN PERNIKAHAN POLIGAMI YANG BERTUJUAN HANYA UNTUK MENDAPATKAN ANAK," Hal. 38.

${ }^{27}$ Ibid., Hal. 39. 
tambahan kewajiban yaitu harus adil dalam menafkahi isteri-isterinya. ${ }^{28}$

3. Hukum Poligami

Seperti menurut Prof. Mahmoed Syaltut bahwa hukum asal dari poligami adalah mubah. ${ }^{29}$ Selain itu hukum poligami cukup beragam, yaitu :

a. Sunnah ketika adanya suatu kerelaan dari isteri pertama, atau dalam hal lain isteri pertamanya sedang dalam keadaan sakit yang tidak memungkinkan isteri tersebut untuk melahirkan keturunan, di satu sisinya lagi seorang suami sudah sangat mendambakan kehadiran anak ditengah-tengah keluarga kecilnya dan dia pun yakin mampu untuk berbuat adil. Nah dalam hal inilah yang menjadikan poligami itu disunahkan karena suatu keadaan yang menuntut dan adanya kemashlahatan yang disyari'atkan. Dan hal ini pula yang dilakukan oleh mayoritas para shahabat.

b. Hukumnya akan berubah menjadi makruh ketika seorang suami ingin berpoligami namun tanpa ada kebutuhan, atau dengan kata lain poligami yang hanya didasarkan pada kenikmatan dan bersenang-senang serta di sisi lain ia juga mempunyai keraguraguan untuk dapat berlaku adil kepada para isterinya nanti.

c. Haram ketika dia yakin bahwa dia memang tidak mampu

${ }^{28}$ Ibid., Hal. 40.
${ }^{29}$ Lihat, Azni, “Izin Poligami di Pengadilan Agama (Suatu Tinjauan Filosofis)," Hal. 59. untuk berlaku adil, mungkin karena faktor kemiskinan, kelemahan atau tidak adanya gairah untuk membagi perhatian kepada para isteri. Maka ini dihukumkan sebagai sesuatu yang haram

Jadi menurut penulis sesuai dengan hal-hal yang dikemukakan di atas bahwa hukum poligami yang dimunculkan Islam dapat berubah sesuai dengan kondisi dan kebutuhan apakah poligami memang perlu, sehingga nantinya dapat menjadi perantara untuk mencapai tujuan pokok pernikahan yaitu sakinah, mawaddah, wa rahmah.

\section{Pembatasan Poligami: Dialektika Masna wa Tsulasa wa Ruba'a}

Alasan pembatasan 4 orang isteri saja yang ditemukan dalam kitab fikih Islam wa adillatuhu karya wahbah az zuhaili dalam kitab beliu bahwa poligami dibatasi agar dapat menutup pintu yang arahnya dapat membawa kepada berbagai penyimpangan. Terkait penyimpangan yang disebut beliau ini dapat dimaknai seperti akan dapat memicu poligami liar, rumah tangga rentan menjadi pecah, tidak terjaminnya ekonomi dan keadilan, ketertindasan perermpuan, dan ketelantaran anak ${ }^{30}$. Juga kasus seperti yang dilakukan laki-laki yakni main serong atau mempunyai wanita 
simpanan, dan wanita penghibur ${ }^{31}$ bagi dirinya. Jika tidak dibatasi maka laki-laki akan mudah untuk nikah lagi dengan perempuan lain sedang dia sudah mempunyai banyak isteri atau lebih dari empat orang. Untuk itulah Islam mengatur kebolehan berpoligami hanya empat orang isteri saja.

Lalu bagaimana dengan pendapat-pendapat yang mengatakan bahwa Rasulullah dulunya mempunyai istri bahkan melebihi dari empat orang ? Mengenai pendapat yang menyatakan bahwa Rasulullah dulu mempunyai lebih dari empat isteri diantaranya dikarenakan :

1. Rasulullah menikahi Zainab karena tidak lain adalah wahyu dari Allah SWT.

2. Rasulullah menikahi Safiyah dengan harapan agar para kabilah yang ada di belakang Syafiah banyak yang masuk Islam.

3. Hafsah binti Umar dan juga Aisyah binti Abu Bakar dinikahi agar terjalin lebih kuat tali silaturrahim sehingga memperekat persabahatan antara beliau dengan dua sahabt ini.

4. Rasulullah menikahi Ummu Salamah untuk melindungi serta meringankan beban hidupnya karena anak-anak Ummu Salamah dalam keadaan yatim. ${ }^{32}$

31 Aulia, "Tinjauan Kriminologis Atas Penyediaan Wanita Penhibur Di Hotel Studi Kasus di Kota Makassar," Hal. 16-34. 32 Muzakki, "SOSIOLOGI GENDER," Hal. 359-360.
5. Rasulullah menikahi Ramlah putri Abu Sufyan ra, dengan tujuan mengangkatnya dari jurang penderitaan sekaligus untuk menarik hati ayah agar masuk Islam karena ayah merupakan salah satu tokoh utama dikalangan kaum musyrikin di Mekkah. ${ }^{33}$

Alasan-alasan tersebut dapat dipahami bahwa Rasulullah sendiri menikah dengan banyak isteri bukan karena dorongan syahwat. Dan fakta lain juga menyebutkan bahwa umur beliau ketika berpoligami yakni pada saat usia sudah mencapai 55 tahun, serta isteri-isteri beliau yang juga rata-rata adalah janda-janda perang kecuali hanya isteri beliau bernama Siti Aisyah yang dinikahi saat masih perawan $^{34}$, jadi dapat dikatakan bahwa Rasullullah murni untuk menyelamatkan kehidupan para janda bukan untuk memenuhi syahwat beliau atau sekedar untuk memuaskan hasrat libido laki-laki. ${ }^{35}$

Ditentang atau tidak ditentang, sejak dulu perkawinan poligami dipandang masyarakat sebagai "bahan gunjingan atau pembicaraan negatif'. Akibatnya, banyak laki-laki yang melakukan perkawinan poligami secara 'sembunyi-sembunyi' dalam arti tidak disebarluaskan. Sikap

33 Hidayat, "Pemikiran Muhammad Quraish Shihab Tentang Poligami," Hal. 72.

34 Muzakki, "SOSIOLOGI GENDER," Hal. 359.

35 Lihat, Supriati dan Fikawati, "Efek Paparan Pornografi pada Remaja SMP Negeri Kota Pontianak Tahun 2008," Hal. 55. 
masyarakat yang memandang negatif terhadap laki-laki yang melakukan perkawinan poligami memang sahsah saja. Banyak pendapat dan asumsi berkembang tentang perkawinan poligami. Banyak komentar dari para ulama yang menyatakan bahwa secara jelas praktik perkawinan poligami adalah sah dan halal menurut ajaran agama Islam. Akibatnya muncul perang adu argumentasi untuk mempertahankan pendapat dengan membeberkan fakta, literatur dan riwayat masa jaman Nabi Muhammad SAW yang kemudian disandingkan dengan kehidupan sekarang sebagai landasan argumentasi dan menyatakan bahwa Rasulullah dulu mempunyai istri lebih dari empat. Tetapi jika dikaji secara mendalam maka akan ada banyak hikmah mengapa poligami dibatasi hanya 4 orang istri saja, karena dampak negatifnya yang cukup banyak.

Kemudian, dalam bertambahnya jumlah isteri dari empat orang menurut kitab fikih islam wa adillatuhu karangan wahbah az zuhaili, beliau menerangkan jika tidak dibatasi hanya 4 orang isteri maka dikhawatirkan timbulnya perbuatan maksiat dari mereka akibat ketidak mampuan memenuhi hak-hak dari isteri-isterinya. Karena secara zahir, seorang laki-laki tidak mampu memenuhi hak-hak mereka.

Kata maksiat yang dimaksudkan oleh Wahbah az Zuhaili seperti pada keterangan di atas dapat saja kita kaitkan dengan era modern, perbuat maksiat akibat poligami tidak dibatasi seperti maraknya tempat pelacuran, prostitusi, pekerja wanita-wanita malam yang mencari nafkah dengan cara menjual diri, dan perbuatan lainnya yang dianggap merendahkan kaum perempuan dan menjadikan mereka sebagai pemuas nafsu birahi lak-laki hidung belang ${ }^{36}$.

Islam yang memberikan ruang untuk mengatur sedemikian rupa pembatasan poligami sebatas empat orang isteri saja dan di tuntut adanya berbuat adil terhadap isteri-isterinya . ${ }^{37}$ Yang dalam hal ini sesuai dengan dasar hukum poligami yang terdapat dalam Q.S AnNisa ayat 3.

Artinya: Dan jika kamu takut tidak akan dapat berlaku adil terbadap (hak-bak) perempuan yang yatim (bilamana kamu mengawininya), maka kawinilah wanita-wanita (lain) yang kamu senangi : dua, tiga atau empat. Kemudian jika kamu takut tidak akan dapat berlaku adil, maka (kawinilah) seorang saja, atau budak-budak yang kamu miliki. Yang demikian itu adalab lebih dekat kepada tidak berbuat aniaya. Akan tetapi pada Q.S An-Nisa ayat 3 tersebut tidak memberikaan penjelasan mengenai kategori adil yang dimaksudkan oleh ayat ini dan

\footnotetext{
36 Lihat, Azni, "Izin Poligami di Pengadilan Agama (Suatu Tinjauan Filosofis)," Hal. 56. Hal. 354.
} 
dalam hal apa saja adil tersebut. ${ }^{38}$ Lalu bermunculanlah berbagai pendapat mengenai keadilan tersebut, salah satunya yang dimaksud keadilan di sini adalah seperti keadilan dalam memnuhi kebutuhan sandang, pangan, papan, dan pembagian giliran menginap unttuk para isteri.

Bersikap adil dalam perkawinan poligami adalah tidak mudah. Karena bentuk bentuk perkawinan poligami tidak seperti dalam perkawinan monogami, dimana suami hanya memiliki satu orang isteri saja. Hak-hak dalam tali perkawinan juga secara otomatis hanya menjadi milik isterinya seorang. Lain halnya hak serta kewajiban suami dan isteri-isterinya dalam sebuah perkawinan poligami yang sangat berbeda dengan perkawinan monogami. Masalah ini juga yang disebutkan oleh Wahbah Az Zuhaili bahwa jika tidak dibatasi hanya 4 orang isteri maka dikhawatirkan timbulnya perbuatan maksiat dari laki-laki akibat ketidak mampuan memenuhi hak-hak dari isteri-isteri yang sudahh dinikahinya tersebut. Karena secara zahir, seorang laki-laki tidak mampu memenuhi hak-hak mereka.

Dalam pernikahan, seorang suami dituntut untuk berlaku adil terhadap istrinnya. Semua sepakat tentang hal ini. Masalahnya adalah keadilan seperti apa ? Apakah

\footnotetext{
38 Ibid., Hal. 358
}

keadilan segala hal, dalam pengertian lahir dan bathin ? Salah satu cara untuk memaknai keadilan dalam berpoligami, ada baiknya menyimak suatu kisah menarik dan memerlukan perenungan berikut ini. "Suatu ketika Nabi Mubammad SAW pernab berkata kepada istri-istri beliau, "Aku berikan semua pada kalian apa yang ada di tanganku." 39

Perkataan Nabi yang singkat di atas, meninggalkan setidaknya dua pesan penting terkait dengan makna keadilan dalam berpoligami. Pertama, bahwa apa-apa yang bersifat material yang ada pada Nabi, mampu diberikan kepada istri-istrinya secara merata dan seimbang. Kedua, bahwa selain yang bersifat material seperti cinta, perhatian, dan kasih sayang adalah sesuatu yang tidak dapat dilakukan oleh Nabi untuk diberikan kepada istri-istri beliau secara merata dan setara. Dalam sebuah hadits yang diriwayatkan oleh imam Ahmad bahwa Nabi sendiri tidak dapat berbuat adil untuk hal-hal yang tidak dimilikinya, yaitu bahasa hati. Suatu ketika Nabi berdoa,"Ya Allah, inilah pembagian dari apa-apa yang kumiliki, maka janganlah mencelaku dalam hal yang Engkau miliki dan aku tidak miliki." $" 40$

Dengan demikian, konsep keadilan diartikan tetap dalam koridor kemampuan sebagai insan

${ }^{39}$ Qultum Media, Poligami Siapa Takut?, (Jakarta: Qultum Media,2006),hlm.28

${ }^{40}$ Ibid, hlm.29. 
yang memiliki keterbatasan, terutama dalam hal-hal yang bersifat bathin seperti keadilan berbagi cinta dan kasing saying.

Menjalani perkawinan poligami tidak semudah membalikan telapak tangan. Karena tidak semua orang memiliki sikap adil dalam arti yang sebenar-benarnya sebagaimana yang dilakukan oleh Nabi Muhammad SAW kepada para isteri-isterinya. Artinya jika tidak bisa berlaku adil, maka sudah termasuk berperilaku zalim. Salah satu ketidakmudahan dalam melakukan perkawinan poligami adalah hukuman yang akan diterima di akhirat kelak. Yaitu jika tidak dapat berbuat adil maka kelak di hari kiamat pundaknya akan miring sebelah ? Benarkah demikian pernyataan tersebut ? Jika memang demikian kenapa masih banyak lakilaki yang tega "diam-diam" menikah dengan wanita lain di belakang istri pertama?

Selama ini menurut penulis sendiri kebanyakan masyarakat masih memandang perkawinan poligami sebagai sesuatu yang negatif. Diantara alasan yang paling umum didengar seperti :

1. Poligami kerap jadi objek kekerasan $^{41}$ terhadap wanita dan anak-anak

Poligami dianggap bukan bentuk perkawinan ideal, ini

41 Lihat, Azni, "Izin Poligami di Pengadilan Agama (Suatu Tinjauan Filosofis)," Hal. 55. maksudnya masyarakat kita lebih mengenal perkawinan 'monogami' sebagai bentuk perkawinan yang ideal yaitu memiliki isteri satu. Dari situlah masyarakat cenderung lebih tinggi menjunjung tinggi perkawinan monogami sebagai perkawinan ideal dan mengganggap perkawinan poligami bukan sebagai perkawinan yang ideal. Perkawinan poligami dianggap sebagai sikap 'tidak setia' terhadap istri dan anak-anak dari perkawinan pertama. Hal itu karena dalam masyarakat kita berkembang pemahaman bahwa perkawinan hanya dilakukan hanya sekali dalam hidupnya. Jadi muncul anggapan kuat bahwa perkawinan ideal adalah jika dalam hubungan suami istri adanya kesetiaan antara suami dan istri. Karenanya jika muncul laki-laki yang melakukan perkawinan poligami kerap menjadi bahan gunjingan.

2. Perakawinan poligami dinilai semata karena seks

Masyarakat seringkali, menganggap laki-laki yang melakukan perkawinan poligami dilatarbelakangi karena "pelampiasan seks" berlebihan kepada wanita. Keadaannya masa jaman Nabi Muhammad dengan jaman sekarang dinilai masyarakat dilatarbelakangi seks. Sehingga laki-laki yang melakukan perkawinan poligami dicap miring dalam kaitan orientasi seksual. Unsur perkawinan poligami kerap dijadikan alasan supaya tidak berzina. Hal ini menurut penulis menyebabkan "konotasi seks" 
perkawinan poligami menjadi negatif terhadap laki-laki yang melakukan poligami.

3. Poligami sebagai faktor pemecah keharmonisan keluarga

Hadirnya orang lain dalam perkawinan seorang laki-laki dengan seorang perempuan dianggap sebagai penyebab pemecah keharmonisan keluarga. Sehingga banyak ketakutan yang di rasakan oleh para wanita, atau para istri dan beranggapan sinis terhadap "perkawinan poligami". Berbagai macam rasa cemas dan khawatir melanda hati kaum perempuan. Bagaimana tidak, mereka takut suaminya kelak melakukan perkawinan poligami yang suatu saat "poligami" itu sendiri dijadikan suami sebagai senjata untuk menikahi wanita lain yang ia kehendaki. Untuk itulah menurut penulis Islam menghadirkan sisi positifnya diadakan adanya pembatasan hanya 4 orang istri untuk berpoligami. Namun tampaknya kontroversi perkawinan poligami akan tetap ada hingga bumi berputar. Akan tetapi, dalam hal ini Islam juga tidak bermaksud merendahkan derajat dari kaum wanitanya. Ini ditandai dengan diturunkannya surah An-Nisa . Justru Rasulullah SAW pun sangat menjujunjung tinggi derajat kaum wanita. Dimasa ketika dijamannya wanita hanya menjadi pelengkap penderita. Dan poligami tersirat di dalam Al Qur'an tujuannya adalah bersifat sosial, bukan untuk memuaskan nafsu seksual. Dan laki- laki yang akan melakukannya dituntut memiliki kemampuan berbuat adil untuk istri-istrinya.

Kemudain jika ditelaah dalam Islam, Poligami (ta'addudu al-jauzah) dalam kitab-kitab fiqih klasik lebih mengacu kepada status seseorang. Orang laki-laki yang merdeka (hurrun) boleh menikahi 4 orang perempuan, sedangkan budak lakilaki (abdun) hanya boleh menikahi 2 orang perempuan. Merdeka atau tidaknya kategori budak menjadi hal yang berpengaruh bagi keputusan hukum yang akan dibebankan. Memang untuk dijaman yang sekarang ini masalah perbudakan sudah dihapuskan tetapi alangkah baiknya untuk kita ketahui guna menambah khazanah keilmuan dengan mengetahui juga masalah aturan poligami untuk budak pada jaman dimana perbudakan masih dilegalkan .Terlepas dari hal itu posisi poligami memang tidak hanya kesanggupan dari segi fisik dan batin saja, melainkan kesiapan dari harta juga sangat diperhatikan. Inilah pertimbangan yang pantas ketika memilah antara yang merdeka dan budak. Dan ketentuan maksimal empat itu merupakan harga mati, artinya seseorang yang sudah beristeri 4 kemudian ia ingin menikah untuk isteri yang ke 5 ia harus menceraikan salah satu dari ke 4 isterinya, setelah itu ia bisa memilih yang ia kehendaki.

Ada dua pendapat tentang batasan maksimal berpoligami, 
jumhur ulama menyimpulkan bahwa lafadz matsna wa tsulatsa wa ruba' mengindikasikan bahwa wawu ataf itu berfungsi sebagai li altakhyir bukan li al-jam'i, berbeda dengan kalangan mazhab dhahiriyyah dan syi'ah imamiyyah yang menyimpulkan bahwa wawunya berfungsi sebagai li al-jam’i sehingga batas maksimal untuk berpoligami adalah sembilan orang isteri. Sedangkan Wahbah al-Zuhaily lebih menguatkan kepada pendapat yang menyatakan bahwa maksimal isteri itu adalah empat. Dengan dilandasi alasan beliau yaitu karena 1 bulan ada 4 minggu menjadikan kemudahan bagi lakilaki untuk dapat membagi waktu bersama isteri-isterinya, pencurahan cinta dan kasih sayang akan lebih mudah dicurahkan kepada isteri-isterinya dalam batas waktu tidak melebihi satu bulan. Selain itu beliau menyatakan bahwa beristeri lebih dari empat itu ditakutkan berbuat aniaya dan lemah dalam memenihi hak-hak para isteri. Hal inilah yang mengindikasikan bahwa laki-laki yang takut untuk tidak berlaku adil maka baginya lebih baik menikah dengan seorang saja. Keadilan ini menyangkut pembagian waktu, jima', dan nafaqah. Pendapat maksimal 4 ini bukan berarti laki-laki boleh menikah lebih dari 1 , hal ini hanyalah merupakan pengecualian yang jarang sekali, bahkan beristeri satu it merupakan hal yang umum dan paling utama. ${ }^{42}$

${ }^{42}$ Wartini, "Poligami," Hal. 246-247.
Sedangkan didalam kitab fikih Sunnah karya Sayyid Sabbiq pembatasan poligami tidak hanya sebatas mampu yang dinilai dari diri sendiri yang akan melakukan poligami tetapi harus uji seleksi dari orang lain. Dalam hal ini yaitu dari instansi atau pengadilan agama yang menangani wilayah tersebut. Jadi instansi inilah yang kemudian berwenang dalam memberikan izin untuk seorang laki-laki dapat menikah lagi atau tidak. Seorang lakilaki yang ingin melakukan poligami harus lulus uji tes kelayakan untuk poligami dalam hal ini berkaitan dengan kelayakan atau kemampuannya secara materi. Seperti digambarkan dalam kitab fikih sunnah disebutkan adanya kemudharatan yang akan ditimbulkan jika poligami tidak dibatasi, karena untuk menjalani kehidupann rumah tangga dengan jumlah isteri dan anak yang banyak tentunya juga perlu biaya yang tinggi, itu artinya akan semakin memberatkan laki-laki untuk membelanjai seluruh anggota inti keluarga. Suami bisa jadi tidak akan mampu melaksanakan kewajibannya itu semua, mengasuh, dan mendidik keluarganya agar menjadi anggota masyarakat yang baik sehingga tidak akan memunculkan permasalahan baru di masyarakat. Akan tetapi jika suami dalam perjalanan poligaminya ternyata memang tidak mampu melaksanakan kewajibannya maka 
Sayyid Sabiq menggambarkan sdampaknya seperti kebodahan akan semakin meluas, angka pengangguran semakin bertambah, banyak isteri dan anak terlantar sehingga dianggap menimbulkan permasalahan baru, penyakit sosial yang merusak tatanan masyarakat. ${ }^{43}$

Bahkan banyak perempuan yang memilih cerai dari pada poligami, tapi masih lebih banyak yang memilih bertahan. Bisa jadi pertimbangannya adalah didasarkan pertimbangan anak yang dipandang sangat membutuhkan sosok seorang ayah, sebagai pelindungnya yang selama ini dicintainya. Mungkin juga karena alasan status sosial "janda" yang tidak ingin disandang karena dipandang akan membawa dampak psikologis yang berkepanjangan. Juga mungkin karena memang ia masing sangat bergantung kepada suami dalam banyak hal khususnya dalam soal keuangan rumah tangga. Tapi, lagi-lagi pilihan poligami selalu harus disesuaikan dengan konteksnya, dan bukan persoalan boleh tidak, tapi ia butuh atau tidak butuh. Dan lagi-lagi memang beristeri lebih dari satu dalam Islam dibolehkan. Salah satunya dalam Al-Qur'an surat AnNisa ayat 3 misalnya yang menyatakan hal poligami. Tapi jangan hanya diambil begitu saja penafsiran ayat tersebut, karena

43 Sayyid Sabiq, Fikith Sunnah 3, penerjemah Khairul Amru Harahap, dkk (Jakarta: Cakrawala Publishing, 2011), hal. 364 harus dikaji, apa manfaat dan mudharatnya beristeri lebih dari satu.

Dan juga penulis sangat setuju dengan pendapat Quraish Shihab yang menyatakan bahwa pilogami diibaratkan seperti pintu darurat dalam pesawat terbang, yang hanya boleh di buka pada saat keadaan yang emergency tertentu, dan yang duduk disamping pintu darurat itu pun haruslah mereka yang memiliki pengetahuan dan kemampuan membukanya serta diperkenankannya membuka jika sudah mendapat izin dari pilot. ${ }^{44}$ Dan ini sejalan dengan apa yang dituangkan Sayyid Sabiq dalam kitab beliau berkenaan masalah poligami yang menyatakan bahwa poligami harus lebih dahulu mendapatkan izin dari instansi yang berwenang mengingat sisi mashlahat dan mudaratnya apakah perlu dilakukan poligami atau tidak.

Di paragraf selanjutnya Sayyid Sabiq menyebutkan bahwa banyak diantara laki-laki yang menelantarkan anak-anak dan isterinya, bahkan menutupi hak mereka sebagai ahli waris, sehingga hal ini menumbuhkan benih permusuhan dan dengki di antara saudara tiri. Permusuhan ini akan terus berkelanjutan dan semakin meluas hingga di kalangan keluarga dan semakin merajalela, di mana setiap isteri berusaha untuk menjatuhkan

44 Hidayat, "Pemikiran Muhammad Quraish Shihab Tentang Poligami,” Hal. 79. 
satu sama lain, bahkan tak jarang berujung pada pembunuhan. ${ }^{45}$

Untuk itu melakukan poligami harus memenuhi persyaratan sebagaimana terkandung dalam lanjutan isi surat An-Nisa, karena itu isteri yang hendak dimadu harus mengetahui apa saja hak-hak yang harus ia terima dalam perkawinan poligami tersebut. Hak-hak yang diterima setiap orang isteri di dalam perkawinan poligami antara lain seperti memiliki rumah sendiri.

Menyinggung masalah "rumah" sebagai tempat tinggal bagi isteri-isteri dalam perkawinan poligami dijelaskan dalam kitab $\mathrm{Al}$ Mughni bahwasanya tidak pantas seorang suami mengumpulkan dua orang isteri dalam satu rumah tanpa ridha dari keduanya. Hal ini karena dikhatirkan akan menjadi penyebab kecemburuan dan permusuhan diantara keduanya. Oleh karena itu disyaratkan kepada laki-laki yang berpoligami hendaknya menyediakan rumah bagi masing-masing isterinya. Sehingga tidak akan terjadi gesekangesakan yang panas antara para isteri atau bentuk permasalahan yang bisa saja berakibat fatal hingga pembunuhan sesama.

Penulis sendiri pun setuju dengan adanya pembatasan 4 orang istri dalam poligami. Karena banyak

45 Sayyid Sabiq, Fikih Sunnah 3, penerjemah Khairul Amru Harahap, dkk (Jakarta: Cakrawala Publishing, 2011), hal. 365 sekali pada kenyataannya kaum perempuan seolah tertindas dan tersakiti. Dalam konteks keluarga, perempuan ditetapkan sebagai pihak yang dipimpin, sedangkan laki-laki adalah pemimpin. Akibatnya, perempuan tidak memiliki hak untuk memutuskan sesuatu dalam keluarga. Disinilah gejalah kekerasan terhadap perempuan pada kasus poligami tampak. Meski demikian, berbagai kalangan yang pro poligami, membantah pengkategorian poligami sebagai praktik kekerasan terhadap perempuan. Mereka mengatakan poligami merupakan suatu bentuk perlindungan terhadap perempuan karena jumlah perempuan lebih banyak dari pada laki-laki, sehingga poligami membantu laki-laki dan perempuan untuk dapat menikmati seks dan memperoleh keturunan. Disamping itu poligami mencegah laki-laki dari penyelewengan dan tindak kekerasan akibat frustasi tidak memperoleh pemenuhan kebutuhan seksual, poligami sekaligus melindungi perempuan karena mereka dapat "berbagi tugas" dalam memuaskan kebutuhan seksual lakilaki. Argumentasi diatas sebenarnya hanya membuat stereotype ideology patriarkby terhadap perempuan semakin nyata. ${ }^{46}$

Bahkan tak jarang juga dalam kasus poligami terjadi kekerasan yang beruntun baik terhadap istri pertama

46 Hikmah, "Fakta Poligami Sebagai Bentuk Kekerasan Terhadap Perempuan," Hal. 5. 
maupun istri kedua. Dimana istri pertama tidak hanya mengalami pengingkaran komitmen perkawinan tetapi juga terjadi tekanan psikologis, ekonomi, seksual hingga fisik. Belum lagi dipandang negatif bahkan sikap sinis masyarakat yang makin merendahkan. Sementara bagi istri kedua, hal yang tidak jauh berbeda juga terjadi. Selama ini ada pandangan bahwa istri kedua mendapatkan keuntungan dari poligami. Misalnya istri kedua selalu mendapatkan keuntungan tidak saja dari segi psikologis (lebih disayang suami) tapi juga dari segi ekonomis. $\mathrm{Hal}$ ini mungkin sesuai dengan anggapan yang beredar di masyarakat bahwa "istri muda lebih disayang ketimbang istri tua." Walaupun demikian istri kedua tetap dihantui kekerasan dari sang suami. Keadaan seperti ini berlaku bagi semua perempuan tanpa memandang tinggi rendahnya status sosial perempuan. Sama dengan istri pertama, maka istri kedua pun tidak luput dari cibiran masyarakat. Seringkali istri muda mendapat label sebagai perempuan "pelanggar kehormatan", perempuan penggoda" dan yang lebih menyedihkan lagi mereka juga dicap sebagai "perempuan binal alias gatal."

Selain itu dampak umum akibat perkawinan poligami terhadap istri antara lain: di dalam diri isteri akan muncul perasaan menyalahkan diri sendiri, istri merasa tindakan suaminya berpoligami adalah akibat ketidakmampuan dirinya memenuhi kebutuhan biologis suaminya ${ }^{47}$. Selama masa perkawinan, sudah ketergantungan secara ekonomi kepada suami. Ada beberpa suami memang dapat berlaku adil terhadap isteri-isteri.tetapi seringkali pula dalm praktiknya, suami lebih mementingkan isteri muda dan menelantarkan isteri yang tidak memiliki pekerjaan akan sangat kesulitan menutupi kebutuhan sehari-hari. Bahkan juga sering terjadinya tindak kekerasan terhadap perempuan dan anank-anak, baik kekerasan fisik, ekonomi, seksual maupun psikologis ${ }^{48}$. Jauh lebih darii itu juga budaya perkawinan poligami akan dikhawatirkan memunculkan "praktek prostitusi"49 makin tinggi. Karena akan memberikan kebebasan kepada laki-laki untuk berganti-ganti pasangan seksual. Hal ini bisa menjadi pemicu munculnya penyakit menular seksual (PMS) ${ }^{50}$ dan bahkan rentan terjangkit HIV/AIDS. ${ }^{51}$

\section{Kesimpulan}

Wahbah az Zuhaili memberikan gambaran dampak dari adanya poligami dimulai dari ketidakmampu-

47 “Rohilah_SyarAkhSyak.pdf," Hal. 34.

48 Lihat, Harnoko, "Dibalik Tindak Kekerasan Terhadap Perempuan,” Hal. 1822183.

49 Lihat, Hasibuan, "Prostitusi Sebagai Penyakit Sosial dan Problematika Penegakan Hukum," Hal. 2-3.

50 Lihat, "Pendidikan Jasmani dan Kesehatan - Google Buku,” Hal. 175-177.

51 Hikmah, "Fakta Poligami Sebagai Bentuk Kekerasan Terhadap Perempuan." Hal. 41-41 
an laki-laki untuk memenuhi hak-hak para isterinya sehingga ini akan menimbulkan perbuatan maksiat di dalam keluarga itu sendiri. Sedangkan Sayyid Sabiq juga memberikan pandangan mengenai dampak poligami yang asal masalahnya sama-sama di dasari karena ketidakmampuan seorang suami. Beliau memberikan gambaran yang jauh lebih kedepan dalam melihat maslahat dan mudharat yang akan ditimbulkan oleh poligami hingga sampai kepada dampak ynag akan diterima oleh lingkungan masyarakat. Menurut beliau bahwa jika jumlah anggota keluarga bertambah maka secara otomatis beban yang akan ditanggung laki-laki akan semakin berat. Bahkan beliau juga memberikan pandangan bahwa langkah tersebut dapat menimbulkan kebodohan juga semakin marak bertambah angka pengangguran , terlantarnya sebagian masyarakat, sehingga para pemuda hanya menjadi penyakit sosial yang dapat merusak tatanan masyarakat. Untuk itulah beliau juga menyebutkan jika ingin berpoligami maka harus ada izin terdahulu dari instansi terkait seperti Pengadilan Agama.

Islam memang merupakan agama yang penuh rahmat. Dengan peraturan-peraturan yang telah dibuat oleh syariat dengan segala hikmahnya termasuk yang sudah dibahas yaitu masalah poligami dengan dampak-dampaknya. Islam memberikan antisipatif yang jauh lebih dahulu muncul sebelum dampak negatif dari poligami itu muncul. Oleh karenanya poligami dibatasi hanya dengan empat orang isteri saja. Dengan dampak negatifnya yang sering muncul akibat poligami antara lain :

1. Membuat pemicu timbulnya permusuhan, iri dengki antara isteriisteri.

2. Membuat keuangan keluarga menjadi terbagi-bagi dengan banyaknya jumlah isteri.

3. Poligami kerap menjadi objek kekerasan terhadap wanita dan anakanak.

4. Poligami dianggap sebagai pemicu terpecahnya keharmonisan keluarga.

Memiliki andil dalam memunculkan permasalahan yang lebih luas dilingkungan masyarakat, seperti budaya poligami dikhawatirkan akan memunculkan praktek prostitusi makin tinggi, laki-laki akan mudah berganti-ganti pasangan sehingga dengan itu pula penyakit seperti HIV/AIDS akan lebih mudah menular. Dan Wahbah Az Zuhaili dengan Sayyid Sabiq yang kedua pandangannya dapat disimpulkan bahwa sama-sama memiliki pandangan yang tidak terlalu jauh perbedaannya. Hanya saja Wahbah az-Zuhaili memberikan pandangan dampak poligami sebatas keleuarga inti itu sendiri sementara itu Sayyid Sabiq memberikan pandang jauh lebih luas. Beliau menggambarkan dampak yang 
dimunculkan akibat poligami sampai pada tatanan lingkungan sosial.

Begitu banyaknya sisi negativenya jika poligami itu sendiri tidak di atur sedemikian rupa dalam Islam. Dan begitu banyak hikmah yang dapat diambil agar kita selalu terhindar dari perbuatan yang sia-sia. Dari alasan-alasan diatas juga menurut penulis cukup menyesali karena betapa negatifnya pandangan masyarakat terhadap "perkawinan poligami”. Akan tetapi kita tidak dapat menyalahkan, karena setiap orang memiliki sikap dan pandangan tersendiri.

\section{Daftar Pustaka}

Ahmad, Dhiyauddin. "Analisis Maslahah Mursalah Terhadap Perjanjian Pernikahan Poligami Yang Bertujuan Hanya Untuk Mendapatkan Anak: Studi Kasus Di Desa Tiremenggal Kec. Dukun Kab. Gresik." Uin Sunan Ampel Surabaya, 2016. Http://Digilib.Uinsby.Ac.Id/49 98/.

Andaryuni, Lilik. "Poligami Dalam Hukum Keluarga Di Dunia Islam." Sipakalebbi' 1, No. 1 (2013). Http://Journal.UinAlauddin.Ac.Id/Index.Php/Sipa kalebbik/Article/View/287.

Aulia, Andi Nurul Avira. "Tinjauan Kriminologis Atas Penyediaan Wanita Penhibur Di Hotel Studi Kasus Di Kota Makassar,” 2016.
Http:/ Repository.Unhas.Ac.Id /Handle/123456789/17969.

Azni, Azni. "Izin Poligami Di Pengadilan Agama (Suatu Tinjauan Filosofis)." Risalah 26, No. 2 (2015): 55-68.

Fatimah, Putri Ajeng. "Waris Kalalah Dalam Pandangan Wahbah AzZuhaily (Tafsir Qs. Al-Nisa'(4) Ayat 12 Dan Ayat 176)," 2011. Http://Www.Repository.Uinjkt. Ac.Id/Dspace/Bitstream/12345 6789/5094/1/Putri\%20ajeng\%2 Ofatimah-Fuh.Pdf.

Fauzi, Rodli Jauhari, Dan Others. "Bisnis Online Ptc (Paid To Click) Studi Perbandingan Antara Hukum Islam Dan Hukum Positif (Kuhperdata)." Uin Sunan Kalijaga, 2013. Http://Digilib.UinSuka.Ac.Id/7502/.

Hanafi-Nim, Siti Nurfadillah, Dan Others. "Hyperseks Dan Akibatnya Dalam Kehidupan Rumah Tangga (Studi Putusan Pengadilan Agama Sleman No. 532/Pdt-G/2000/Sm)." Uin Sunan Kalijaga Yogyakarta, $2010 . \quad H t t p: / / D i g i l i b . U i n-$ Suka.Ac.Id/Id/Eprint/ 4863.

Harnoko, Bambang Rudi. "Dibalik Tindak Kekerasan Terhadap Perempuan." Muwazah 2, No. 1 (2012). Http://E-Journal.StainPekalongan.Ac.Id/Index.Php/M uwazah/Article/View/16. 
Hasibuan, Syafruddin. "Prostitusi Sebagai Penyakit Sosial Dan Problematika Penegakan Hukum," 2006.

Hidayat, Rahmat. "Pemikiran Muhammad Quraish Shihab Tentang Poligami." Universitas Islam Negeri Maulana Malik Ibrahim, 2008. Http:/ /Etheses.UinMalang.Ac.Id/4321/1/0421001 2.Pdf.

Hikmah, Siti. "Fakta Poligami Sebagai Bentuk Kekerasan Terhadap Perempuan." Sawwa: Jurnal Studi Gender Dan Anak 7, No. 2 (2012): 1-20.

Islam, Hukum Poligami. "A. Pengertian Poligami." Diakses 2 Mei 2017. Http://Library.Walisongo.Ac.Id /Digilib/Files/Disk1/6/Jtptiain -Gdl-S1-2004-Masrohan21-297$\mathrm{Bab}+\mathrm{Ii}+2-3 . \mathrm{Pdf}$.

Khoirin, Nur. "Menyoal Izin Poligami Bagi Pns." Yin Yang 5, No. 2 (2010): 227-242.

Muhafid, Khanif, Dan Others. "Studi Kritis Terhadap Pemikiran AsSayyid Sabiq Tentang Wakaf Uang Dan Relevansinya Di Indonesia Proposal Skripsi." Uin Sunan Kalijaga, 2014. Http://Digilib.Uin-

Suka.Ac.Id/12839/.

Muzakki, Ahmad. "Sosiologi Gender: Poligami Perspektif Hukum Islam." Lisan Al-Hal: Jurnal
Pengembangan Pemikiran Dan Kebudayaan 8, No. 2 (2016): 353372.

Nabil, Muhammad Faried, Dan Others. "Tinjauan MaqâȘid AsySyarîah Terhadap The Code Of Personal Status Tahun 1958 Pasal 18 Tentang Poligami Di Tunisia." Uin Sunan Kalijaga Yogyakarta, 2015. Http://Digilib.UinSuka.Ac.Id/Id/Eprint/17278.

Nikmah-Nim, Khilyatun, Dan Others. "Wahbah Az-Zuhaili Dan Istidlalnya Tentang Zakat Properti." Perpustakaan Uin Sunan Kalijaga Yogyakarta, 2008. Http://Digilib.UinSuka.Ac.Id/638/.

Pemberian, Sayyid Sabiq Tentang, Dan Hibah Kepada Anak-Anak. "Persetujuan Pembimbing." Diakses 16 Mei 2017. Http://Digilib.Walisongo.Ac.Id /Files/Disk1/79/Jtptiain-GdlSholikin21-3947-1-Coferdl_.Pdf.

"Pendidikan Jasmani Dan Kesehatan Google Buku." Diakses 1 Juni 2017.

Https://Books.Google.Co.Id/B ooks?Hl=Id\&Lr=\&Id=_Pcuaqu ud0uc\&Oi $=$ Fnd $\& \operatorname{Pg}=\operatorname{Pr} 3 \& D q$ $=$ Pengertian + Penyakit + Menular + Seksual $+(+$ Pms +$) \& O t s=$ Fvds xkf9nd\&Sig $=$ Fxvdlwbpt3fijxgne 94ucm0k86s\&Redir_Esc $=\mathrm{Y} \# \mathrm{~V}$ $=$ Onepage $\& Q \& F=$ False. 
"Rohilah_Syarakhsyak.Pdf." Diakses 1

Sabiq sayiid, al fiqh al sunnah, (bairut: Juni 2017. darul fikri, 1983)

Http:/ Eprints.Radenfatah.Ac.I d/244/1/Rohilah_Syarakhsyak. Pdf.

Supriati, Euis, Dan Sandra Fikawati. "Efek Paparan Pornografi Pada Remaja Smp Negeri Kota Pontianak Tahun 2008." Makara Sosial Humaniora 13, No. 1 (2009): 48-56.

Ulfah, Maria. "Poligami Menurut Muhammad Syahrur Dalam Pandangan Hukum Islam," 2011.

Http://Www.Repository.Uinjkt. Ac.Id/Dspace/Bitstream/12345 6789/4276/1/Maria\%20ulfaFsh.Pdf.

Wartini, Atik. "Poligami: Dari Fiqh Hingga Perundang-Undangan." Hunafa: Jurnal Studia Islamika 10, No. 2 (2013): 237-268.

Aziz, abdul dahlan, ensiklopedi hukum islam, (jakarta: pt ichtiar baru van hoeve, 1997, jilid 5)

Sahrani,sohari. Fikih munakahat. Jakarta: raja grafindo persada, 2010. Cetakan ke ii

Sabiq,sayyid, fiqih sunnah. Bandung: alma'arif, 2008. Cetakan xx

Qultum media, poligami siapa takut?, (jakarta: qultum media,2006)

Az-zuhaili wahbah, fikih islam wa adillatubu, (damaskus: dar alfikr,1985), hal. 167 